\title{
Hypopharyngeal Cancer pT3 TNM Finding v6
}

National Cancer Institute

\section{Source}

National Cancer Institute. Hypopharyngeal Cancer pT3 TNM Finding v6. NCI Thesaurus. Code C64451.

Hypopharyngeal cancer with tumor size more than 4 centimeters in greatest dimension, or with fixation of the hemilarynx. (from AJCC 6th Ed.) 